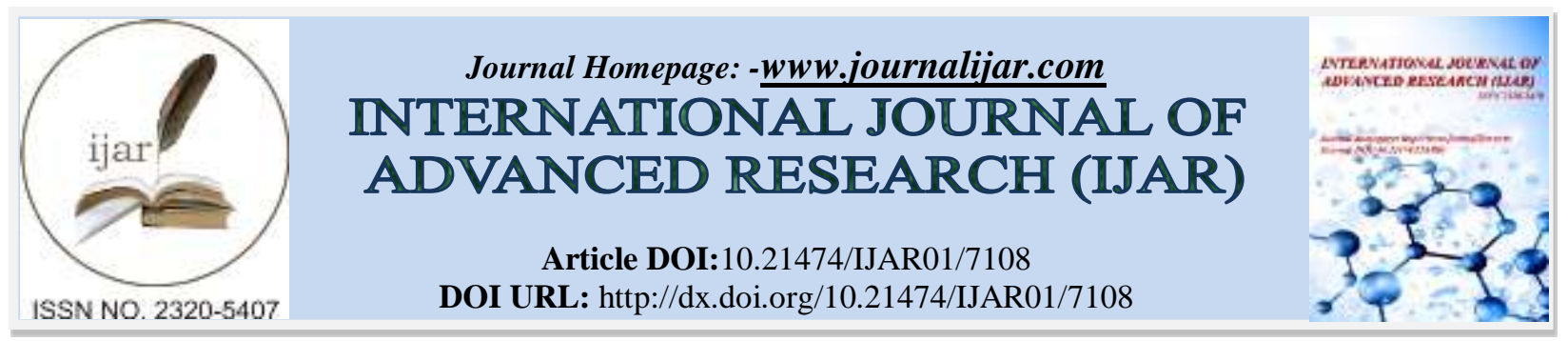

RESEARCH ARTICLE

\title{
GUIDED BONE REGENERATION WITH BIOMATERIAL USE AND REABORESORVABLE MEMBRANE: A CASE REPORT.
}

\section{Amanda Pádua Proêza ${ }^{1}$, Marcela Moráo Corteletti ${ }^{1}$, Helyda Coelho Guimarães Balbino ${ }^{1}$, Fábio Matos}

Chiarelli ${ }^{2}$, Jefferson David Melo de Matos ${ }^{3}$ and Guilherme da Rocha Scalzer Lopes ${ }^{4}$.

1. School of Dentistry, Faculdade São Francisco de Assis ESFA, Santa Teresa - ES, Brazil.

2. Professor of Oral Implantology, Department of Dentistry, Faculdade São Francisco de Assis ESFA, Santa Teresa - ES, Brazil.

3. Post Graduate Student - Masters Degree Program, Department of Prosthodontics, Universidade Estadual Paulista Júlio de Mesquita Filho UNESP, São José dos Campos - SP, Brazil.

4. Post Graduate Student - Ph.D Program, Department of Prosthodontics, Universidade Estadual Paulista Júlio de Mesquita Filho UNESP, São José dos Campos - SP, Brazil.

\section{Manuscript Info}

(..........................

Manuscript History

Received: 15 March 2018

Final Accepted: 17 April 2018

Published: May 2018

Keywords:-

Bone Regeneration; Bone

Transplantation; Dental Implants.

\section{Abstract}

Introduction: Guided Bone Regeneration (GBR) is a surgical procedure that uses graft materials and membranes as a barrier to stimulate a new bone formation over defects. Case Report: The patient A.D.C, leucoderma, 54 years old, attended the dental clinic of the Faculty of São Francisco de Assis (ESFA). A clinical examination was performed and erythematous areas were seen at the gingival border and the papillae. Thus, intraoral radiographs were realized to obtain more information and, after that, the presence of periodontal disease with furcation assessment and a root fracture was observed. Discussion: The clinical case described was carried out following the principles of resorbable barriers with a hydroxyapatite material, it was kept in position to retain the clot and the appropriate dimensions of the alveolar bone associated with the biomaterial. Conclusion: The use of resorbable membranes is efficient in the process of guided bone regeneration, acting as a barrier to the invagination of the soft tissues existing in the bone defects areas.

Copy Right, IJAR, 2018,. All rights reserved.

\section{Introduction:-}

The use of dental implants is one of the most effective methods for oral rehabilitation in dentistry. However, for its use, a bone remnant is needed to guarantee the stability of the implant and, consequently, to allow osseointegration ${ }^{1}$. Different factors could negatively influence bone quality and quantity in oral rehabilitation. Therefore, different techniques were developed to restoring bone defects and enable the implant insertion ${ }^{2}$.

Guided bone regeneration (GBR) is a surgical procedure that uses biomaterials to fill and membranes to stimulate a new bone formation in regions of interest ${ }^{3}$. This technique is predictable for correction of defects of the alveolar bone because it selects osteoblastic cells, which are compatible with the neoformation of bone tissue. The membranes act as physical barriers, preventing the movement of the clot that leads to the formation of a 
vascularization (angiogenesis), chemotaxis and the formation of a new tissue, which ensures the maintenance of the bone dimensions ${ }^{4}$.

Autogenous bone is the main material used to repair maxillary defects, being considered gold standard. Their use may be associated with other biomaterials, or not. Regardless of the filling material, the membranes allocated over the filled defect prevent the permeation of soft tissues ${ }^{5}$. The GBR technique is usually used for bone reestablishment, among them: fenestration or dehiscence around the implant, to compensate for greater deficiencies of the jaws or to avoid bone resorption after exodontia ${ }^{6}$.

GBR allows the thickness and height of the alveolar ridge to be preserved post-extraction ${ }^{7}$. This technique controls the epithelial cell infiltrate in the alveolus, at the same time that the proliferation of connective tissue cells within the alveolus occurs. For such events to occur predictably, oral exposure is contraindicated ${ }^{8}$.

Thus, the present study aims to report a clinical case of guided bone regeneration, in which a first molar (36) was extracted, using biomaterial and resorbable barrier in order to achieve bone formation in the post-exodontia alveolus, to insert a dental implant and reestablish the lost tooth.

\section{Case Report:-}

The patient A.D.C, leucoderma, 54 years old, attended the dental clinic of the Faculty of São Francisco de Assis (ESFA). A clinical examination was performed and erythematous areas were seen at the gingival border and the papillae. Thus, intraoral radiographs were realized to obtain more information and, after that, the presence of periodontal disease with furcation assessment and a root fracture was observed (Fig. 1) and (Fig. 2).

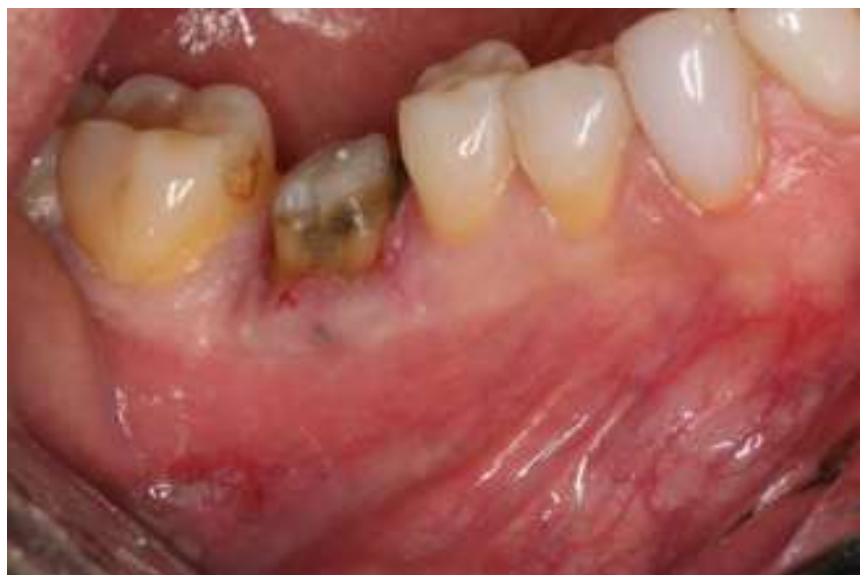

Figure. 1:-Initial appearance of the lower first molar (36) after prosthetic crown removal.

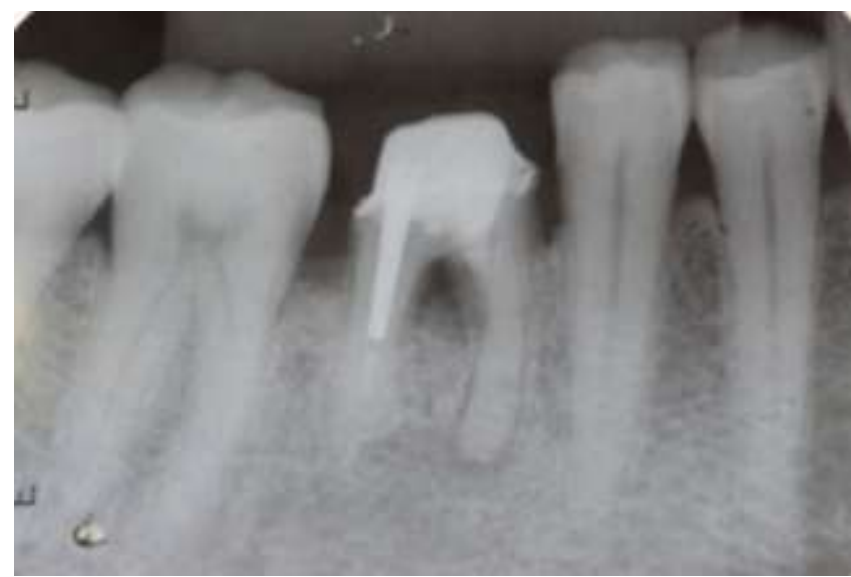

Figure. 2:-Intraoral radiography of lower first molar (36) showing periodontal disease with furcation assessment. 
Considering the clinical examination, complementary radiographic examinations, such as panoramic radiography, were requested to allow a two - dimensional analysis of jaws morphology, location of important structures and anatomical structures.

After clinical and radiographic evaluations, the extraction of the tooth with alveolar preservation and cleaning of the lesion was planned, for posterior treatment with dental implant and single crown. Thus, tooth extraction was performed preserving the interradicular septum and alveolar bone. Cleansing of the lesion was performed with curettes dental and irrigation with physiological saline until the removal of all granulation tissue. After these procedures, the alveolus dental was filled with the biomaterial (Alobone ${ }^{\circledR}$ - Osseocon Biomaterias), wich the control of the chemical composition, crystallinity, presence of pores and particle size of the granules produced is directly related to its in vivo function, where its main advantages are: synthetic biomaterial; low crystallinity; porous granules; high surface area and easy handling. Then, was used a resorbable collagen membrane (Lumina Coat ${ }^{\circledR}$ Critéria Biomateriais), in which it is a natural organic membrane derived from the demineralized bovine bone, composed by collagen type I, biocompatible and sterile. It allows the exchange of fluids and absorption by the tissues, also contributing to the protection of the new bone formed in grafted sites. Its process ensures the preservation of the characteristics of a denatured and extracellular collagen with purity required for surgical applications and free of immunological reactions, favoring the formation of blood vessels through its fibrous structure and acting as a barrier for invagination of soft tissues in the sites of bone defects (Fig. 3) and (Fig. 4).

Five months after the GBR was performed in the region of the tooth loss, a new procedure was performed for the insertion of a cone morse (CM) implant $\varnothing 4.3 \times 10.0 \mathrm{~mm}$ (Drive - Neodent ${ }^{\circledR}$ ). This implant is produced in commercially pure titanium (Grade 4), has a macrosurface with a prosthetic interface with internal hexagonal index; double and progressive threads, in which they facilitate the allocation of the dental implant; still have a high bone compaction power. The implant CM Drive is indicated for the surgical in bone type III and IV, either in the maxilla or mandible. It can be used as a support for single or multiple prostheses, in an immediate or conventional loading protocol. After the implant insertion was completed, a healling abutment was inserted in the same time, thus avoiding the need for a second surgery (Fig. 5), (Fig. 6) and (Fig. 7).

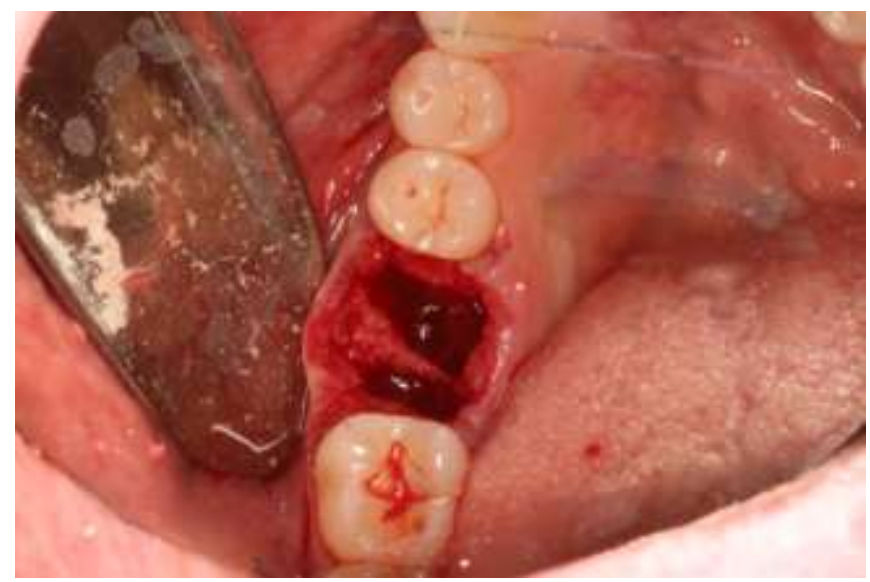

Figure. 3:-Alveolus post-exodontia of lower first molar (36). 


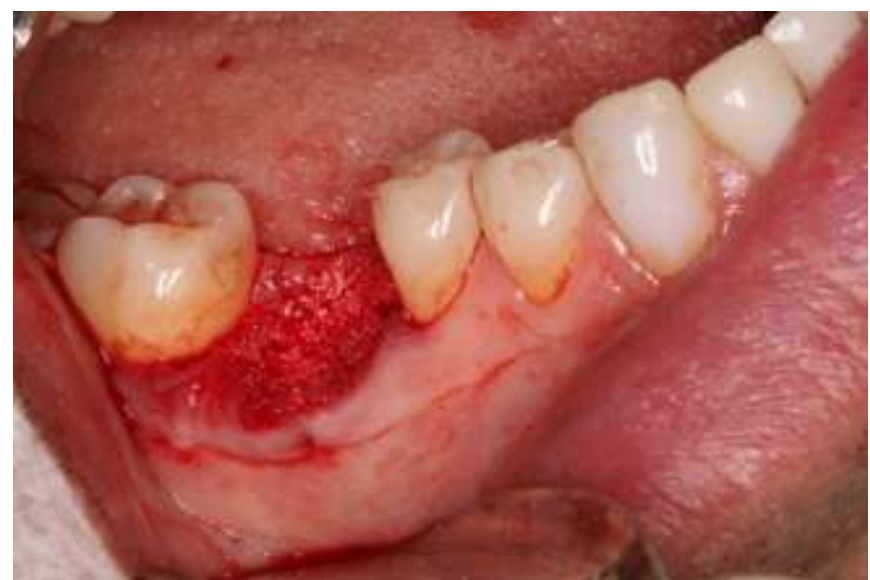

Figure. 4:-Filling the post-extraction alveolus with biomaterial and resorbable collagen membrane.

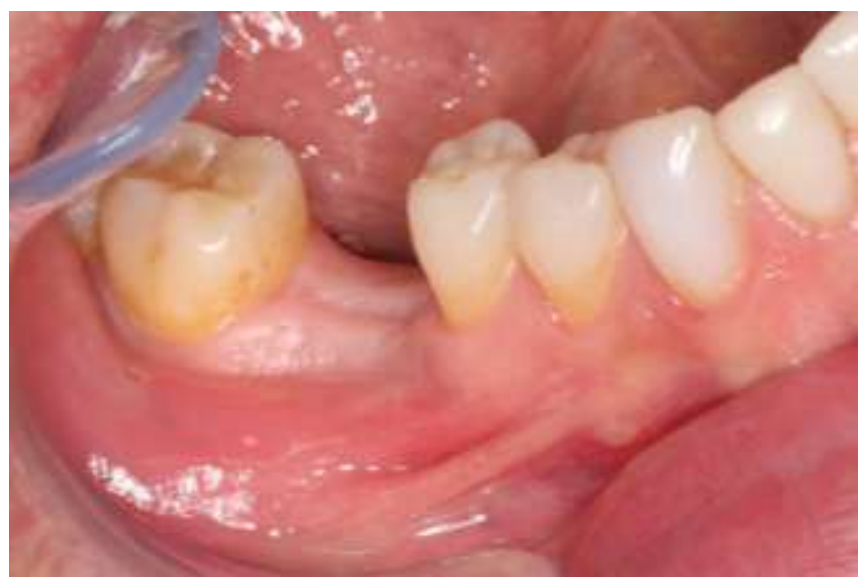

Figure. 5:-Lower first molar (36), five months after GBR surgery.

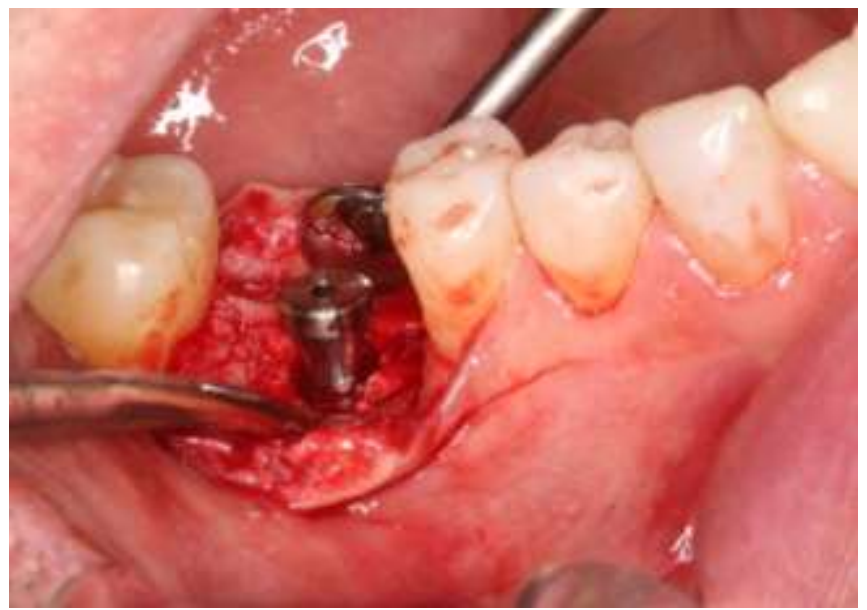

Figure. 6:-Implant and healing abutment insertion in the lower first molar (36) area. 


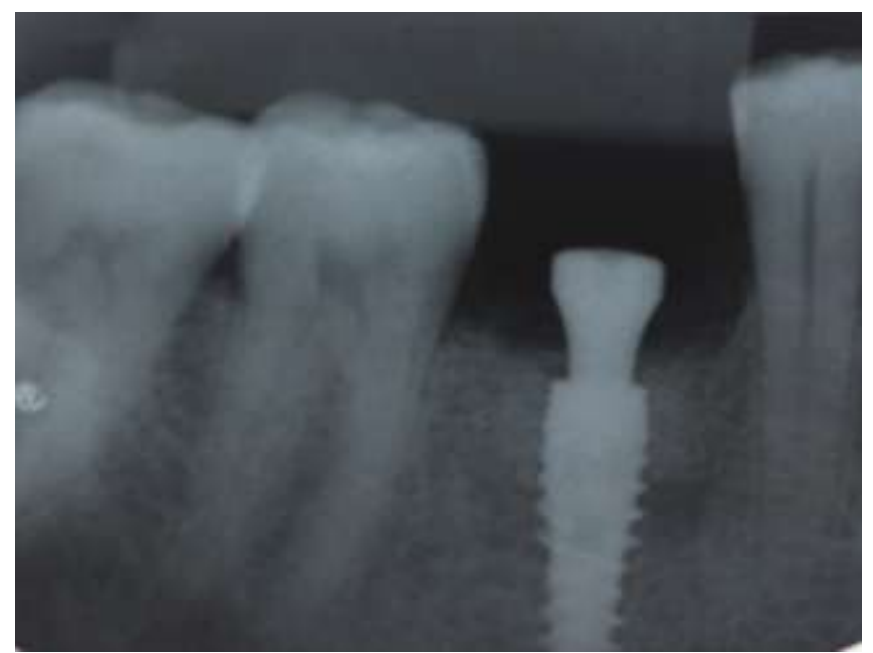

Figure 7:-Intraoral radiography of the dental implant in the lower first molar (36) area.

After a period of approximately 90 days, the rehabilitative planning of the case was continued with the installation of a single screwed prosthesis.

\section{Discussion:-}

A considerable increase in dental implant insertion is observed in partially or totally edentulous patients, due to the good prognosis in the treatment with implants in long term, the improvement of the techniques and the available biomaterials ${ }^{9}$. The use of osseointegrated implants is dependent on bone quantity and in some cases the region being treated may present with a bone deficiency that makes such treatment impossible ${ }^{10}$.

After tooth loss, there are no more stimuli in the alveolar bone, so a reabsorption process begins, which tends to stabilize after a few months ${ }^{11}$. This reabsorption, in most cases, results in bone deficiencies in height, thickness or in the association of these ones ${ }^{12}$. Not infrequently, there is a continuity of this process that can lead to total loss of alveolar bone, which can lead to severe atrophic jaws ${ }^{13}$.

The bone defects in height present in the alveolus post extraction are one of the major challenges for dentists in the rehabilitation of these areas ${ }^{14-17}$. This is due to the difficulty of recovering the lost bone volume, since several techniques fail to allow an accelerated migration and formation of epithelial and connective tissue, when compared to the osteogenic cells, necessary for the bone formation and filling of the region ${ }^{18}$. Thus, aiming for selective cell migration, we have GBR, a technique that allows the exclusion of undesirable cells in the region of the defect through membranes, which act as barriers and favor the proliferation of specific cells to recover the appropriate tissues ${ }^{19}$.

It is considered essential to maintain the blood clot for three-dimensional maintenance of the alveolus, as well as for the success of grafting techniques ${ }^{20-22}$. Following this principle, the blood clot needs to be kept in the tooth area that has been lost, to undergo a satisfactory bone repair, with a correct cicatrization of the edentulous alveolus ${ }^{23,24}$.

The clinical case described was performed following the same principle of the barrier through a reabsorbable collagen membrane with an inorganic mineral, hydroxyapatite, where this barrier was kept in position to retain the clot and maintain the dimensions of the alveolar bone and simultaneously with the biomaterial, led to the process of regeneration of vestibular wall previously lost due to periodontal disease (furcation assessment) and root fracture. Therefore, the results obtained were very satisfactory for vestibular alveolar wall regeneration, maintenance of the bone and soft tissues, permitting final rehabilitation with a single dental implant.

\section{Final considerations:-}

It can be concluded from this study that:-

The use of resorbable membranes is efficient for guided bone regeneration, requiring only one surgical time. Therefore, they guarantee the preservation of the characteristics of a denatured and extracellular collagen, favoring 
the formation of blood vessels through its fibrous structure and acting as a barrier to the invagination of the soft tissues existing in the bone defects areas.

\section{Conflicts of interest:-}

The authors declare that there are no conflicts of interest.

\section{References:-}

1. Pelegrine AA, Aloise AC, Zimmermann A, de Mello E Oliveira R, Ferreira LM. Repair of critical-size bone defects using bone marrow stromal cells: a histomorphometric study in rabbit calvaria. Part I: use of fresh bone marrow or bone marrow mononuclear fraction. Clin Oral Implants Res. 2014 May;25(5):567-72.

2. Maurette AME, Brien MO, Mazzonetto R. Evaluación clínica y radiográfica de la técnica de distracción osteogénica en la reconstrucción de rebordes alveolares atróficos en la región anterior del maxilar superior. Revista Española de Cirugía Oral y Maxilofacial. 2005; 27(3): 137-142.

3. Carvalho PSPD, Rosa AL, Bassi APF, Pereira LAVD. Biomateriais aplicados a implantodontia. Implant News. 2010; 7(3):56-65.

4. Chiapasco M, Casentini P, Zaniboni M. Bone augmentation procedures in implant dentistry. Int J Oral Maxillofac Implants. 2009; 24(7): 237-259.

5. Costa JBZ, Silva F, Almeida Dultra C, Souza LF, Santos MCNE. O uso de membranas biológicas para regeneração óssea guiada em implantodontia: Uma revisão de literatura. Revista Bahiana de odontologia. 2016; 7(1): 14-21.

6. Hämmerle $\mathrm{CH}$, Araújo MG, Simion M. Evidence-based knowledge on the biology and treatment of extraction sockets. Clinical oral implants research. 2012; 23(5): 80-82.

7. Irinakis T, Tabesh M. Preserving the socket dimensions with bone grafting in single sites: an esthetic surgical approach when planning delayed implant placement. Journal of Oral Implantology. 2007; 33(3): 156-163.

8. Maurette MD, O'Brien PM, Sgarbi R, Mazzonetto R. Reconstrução do rebordo alveolar atrófico na região anterior de maxila por meio de distração osteogênica. relato de caso clínico. Revista de Cirurgia e Traumatologia Buco-Maxilo-Facial. 2005; 5(2): 33-40.

9. McAllister BS, Haghighat K. Bone augmentation techniques. J Periodontol. 2007 Mar;78(3):377-96.

10. Melcher AH. On the repair potential of periodontal tissues. Journal of periodontology. 1976; 47(5): 256-260.

11. Pelegrine AA, Aloise AC, Zimmermann A, de Mello E Oliveira R, Ferreira LM. Repair of critical-size bone defects using bone marrow stromal cells: a histomorphometric study in rabbit calvaria. Part I: use of fresh bone marrow or bone marrow mononuclear fraction. Clin Oral Implants Res. 2014 May;25(5):567-72.

12. Nóia FC, Andrade CV, Lopes OR, Mazzonetto R. Distração osteogênica alveolar e osteotomia segmentar com enxerto interposicional: revisão de literatura e considerações clínicas. Rev Elet Facimed. 2011; 3(31): 322-31.

13. Salomão M, Siqueira JTTD. Regeneração óssea guiada através de barreira exposta ao meio bucal após exodontias. Relato de caso. Rev Bras Implant. 2010: 5-7.

14. Salomão M., Siqueira J.T.T. Uso de barreira exposta ao meio bucal para regeneração óssea guiada após a exodontia. Rev. Assoc. Paul. Cir. Dent. 2010; 64(3):184- 8

15. Bugarin Jr JG, Garrafa V. Bioética e biossegurança: uso de biomateriais na prática odontológica. Rev. saúde pública. 2007;41(2):223-8.

16. Lekovic V, Camargo PM, Weinlaender M, Kenney EB, Vasilic N. Combination use of bovine porous bone mineral, enamel matrix proteins, and a bioabsorbable membrane in intrabony periodontal defects in humans. J. periodontol. 2001;72(5):583-589.

17. Bunyaratavej P, Wang HL. Collagen membranes: a review. J. periodontol. 2001;72(2):215-29.

18. Serra e Silva FM, Germano AR, Moreira RWF, Morais M. Membranas absorvíveis x nãoabsorvíveis na Implantodontia: revisão da literatura. Rev. cir. traumatol. buco-maxilo-fac. 2005;5(2):19-24.

19. Lima JFM, Matos JDM, Santos JPS, Oliveira AJAG, Vasconcelos JEL, Zogheib LV, Castro DS. Maxillary sinus lift surgery techniques: A literature review. Int. J. of Adv. Res. 2017; 5(8): 832-844.

20. Santos IKS, Matos JDM, Júnior CUFS, Oliveira AJAG, Franco JMPL, Vasconcelos BCG; Vasconcelos EMGM, Gomes TN, Vardiero VA, Vasconcelos JEL. Surgery of the maxillary sinus with piezocirurgic system use: Case report. Int J Inf Res Rev. 2017; 4(6): 4258-4260.

21. Pereira ALC, Matos JDM, Cavalcante-Pereira N, Franco JMPL, Vasconcelos BCG, Vardiero VA, Gomes TN, Vasconcelos, J. E. L. Maxillary Sinus lift and use of L-PRF with a delayed installation of implants-Case report. Int. J. of Dev. Res. 2017; 7(6): 13174-13177. 
22. Matos JDM, Santos IKS, Perreira ALC, Oliveira, AJAG, Vasconcelos BCG, Pita Neto IC. Vasconcelos JEL. The use of the rich fibrin in platelets and leukocytes as alternative treatment for lifting the maxillary sinus - A literature review. Int. J. of Dev. Res. 2017; 7(6): 13436-13441.

23. Taba Jr M, Jin Q, Sugai JV, Giannobile WV. Current concepts in periodontal bioengineering. Orthod. craniofac. res. 2005;8(4):292-302.

24. Wikesjö VME, Lim WH; Thomson RC; Hardwick WR. Periodontal repair in dogs: gingival tissue occlusion, a critical requirement for GTR? J. clin. periodontol. 2003;30(7). 